PARADIGMA JURNAL KAJIAN BUDAYA Vol. 6 No. 2 (2016): 187-195

\title{
KETIADAAN PADANAN PERIBAHASA PRANCIS DALAM BAHASA INDONESIA
}

\author{
Ismirani Mardalena \\ Mahasiswa S2 Linguistik Fakultas IImu Pengetahuan Budaya Universitas Indonesia, ismiranimardalena@gmail.com
}

DOI: $10.17510 /$ paradigma.v6i2.96

\begin{abstract}
The absence of equivalents is an issue that has always been faced by translators in translating the source text. When translating proverbs, which are loaded with moral and cultural messages, translators are required to be able to transfer the messages appropriately. The different types of proverbs between French and Indonesian are a major cause of translators' difficulty in finding the equivalents in the form of proverbs. This issue was raised from the author's own experience in translating French fable by Jean de La Fontaine into Indonesian. By using the theory of Paremi and proverbs types of Bhuvaneswar (2000), French and Indonesian proverbs are analyzed in order to find the kinds of proverbs of the source language and the target language. It was found that the absence of equivalents in the form of Indonesian proverbs caused by the opposite of types of French proverbs and Indonesian proverbs. The majority of French proverbs are literal, whereas Indonesian proverbs are mostly metaphors. Data were taken from the fables of Jean de La Fontaine and its translation into Indonesian.
\end{abstract}

\section{KEYWORDS}

Translation problems; translation of literary text; equivalence; proverb.

Penggunaan peribahasa di dalam karya sastra sudah ada sejak berabad-abad yang lalu. Whiting (1932) dalam Honneck $(1997,11)$ mencatat bahwa peribahasa memiliki peran yang sangat penting dalam karya sastra Yunani dan Roman. Filsuf ternama, seperti Socrates, Plato, dan Aristoteles menggunakan peribahasa dalam karya filosofi mereka. Di Eropa, khususnya di Prancis, penggunaan peribahasa dimulai dari abad Antik dan mencapai puncaknya di abad pertengahan (abad XI-XV) dan klasik (abad XVI-XVIII).

Pada abad XVII, aliran klasik dan barok mewarnai perkembangan karya sastra di Prancis. Penulis terkenal pada abad itu yang menggunakan peribahasa adalah Molière dengan karya teater komedinya dan Jean de La Fontaine dengan karyanya Les Fables de La Fontaine. Karya Molière dan La Fontaine bertujuan untuk mengkritik keadaan sosial dan politis pada zaman itu. Mengingat pentingnya fungsi dan penggunaan peribahasa dalam karya sastra, penulis ini telah melakukan penelitian yang membahas faktor penentu keberhasilan penerjemahan peribahasa Prancis ke bahasa Indonesia dalam bentuk anotasi terjemahannya sendiri. 
Selama menerjemahkan karya tersebut, penulis ini menemukan masalah dalam menemukan padanan berupa peribahasa BSa. Penyebabnya, di antaranya adalah perbedaan kata kunci yang digunakan dalam peribahasa BSu ataupun BSa, dan perbedaan sudut pandang penyampaian pesan. Oleh karena itu, dalam penelitian ini, ia membahas kesepadanan peribahasa BSa denga peribahasa Prancis.

Penulis ini memilih enam belas fabel karya Jean de La Fontaine (1968 dan 1978) sebagai sumber data karena dua alasan. Pertama, fabel itu mengandungi peribahasa yang memainkan peran penting pada setiap kisahnya. Kedua, sumber data itu merupakan teks sumber dan TSa hasil pekerjaan penulis ini.

Dari enam belas peribahasa Prancis yang dijadikan data, ditemukan hanya tujuh peribahasa BSu yang memiliki padanan berupa peribahasa BSa. Sisanya, sembilan peribahasa BSu diterjemahkan dalam bentuk parafrase. Melihat sulitnya menemukan peribahasa Indonesia yang berpadanan dengan peribahasa Prancis, muncul pertanyaan apa penyebab ketiadaan padanan berupa peribahasa dalam penerjemahan peribahasa Prancis ke bahasa Indonesia?

Untuk meneliti penerjemahan peribahasa Prancis ke bahasa Indonesia seperti yang telah disebutkan di atas, digunakan beberapa teori sebagai kerangka pikir, baik yang berkaitan dengan konsep peribahasa maupun dengan penerjemahannya.

Membahas peribahasa, sama dengan membahas freseologi, khususnya paremi. merupakan salah satu cabang ilmu yang termasuk ke dalam fraseologi, khususnya fraseologi paremiologis.

Paremi menurut Muñoz (1992) dalam Rey $(2002,75)$, adalah satuan fungsional bahasa yang singkat, berbentuk kalimat, kuno, dan dapat disisipkan di dalam teks. Rey menambahkan bahwa paremi adalah elemen terkecil bahasa yang dapat berbentuk peribahasa, pepatah, kata-kata mutiara, kalimat, pameo, dsb.

Uraian di atas menunjukkan bahwa peribahasa merupakan salah satu bentuk paremi. Berdasarkan uraian itu, dalam penelitian ini, peribahasa akan dianalisis dari perspektif karakter paremi. Karakter itu adalah berupa gabungan dua atau lebih kata, berstruktur beku, tertutup, dapat mengandungi dua makna, yaitu makna literal dan kiasan, serta sarat akan pesan moral. Karakter, struktur, dan jenis peribahasa akan dijelaskan secara terperinci berikut ini.

\section{Peribahasa}

Mieder $(1993,5,24)$ mendefinisikan peribahasa sebagai "kalimat pendek yang ada dalam masyarakat yang mengandungi unsur kebijaksanaan, kebenaran, moral, dan pandangan tradisional dalam bentuk metafora, berbentuk baku, dan selalu diingat serta diturunkan dari satu generasi ke generasi yang lain". Sementara itu, Norrick $(1985,40)$ memberikan definisi peribahasa sebagai ... a traditional, conversational, didactic genre with general meaning, a potential free conversational turn, preferably with figurative meaning.

Dengan demikian, dapat disimpulkan bahwa peribahasa adalah ungkapan idiomatis yang tetap penggunaannya, berstruktur beku dan berbentuk ringkas, memiliki makna didaktik, dan dapat juga bermakna kiasan, mengandungi unsur kebijaksanaan, kebenaran, dan moral. Peribahasa digunakan oleh masyarakat secara luas melalui transfer budaya dari generasi ke generasi.

\section{Karakteristik dan Struktur Peribahasa}

Menurut Mieder (2004) peribahasa merupakan salah satu jenis tuturan atau ungkapan tradisional atau disebut juga teks tradisional karena memperlihatkan ciri-ciri sebagai berikut.

1. Strukturnya bersifat tetap; artinya urutan antarunsur tidak dapat dipermutasikan, dan di antara unsur-unsur tidak dapat disisipkan kata atau unsur lain. Teks harus dianggap sebagai suatu 
kesatuan. Artinya, salah satu unsurnya tidak dapat diberi penjelas tersendiri. Misalnya peribahasa La vie est dur (hidup itu keras), jika diberi penjelas -très- (sangat) menjadi La vie est très dur (hidup itu sangat keras), identitas tuturan itu berubah sama sekali.

2. Kata-kata pembentuk teks itu tidak dapat diganti oleh kata lain; jika diganti, akan memiliki maksud yang berbeda.

Silverman-Weinreich (1978) dalam Honeck (1997, 13-14) memerinci karakteristik peribahasa berdasarkan sudut pandang linguistik. Menurutnya, peribahasa merupakan satu kesatuan antara fonologi, sintaksis, dan semantik. Peribahasa dapat berstruktur frase, klausa, atau kalimat, baik yang berstruktur kalimat tunggal maupun kalimat majemuk, dan dapat berkonstruksi kalimat imperatif, baik imperatif positif maupun imperatif negatif; interogatif; komparatif; perumpamaan; dan elipsis. Peribahasa memiliki dua karakter gramatikal: subjek dan predikat, satu penanda semantis (metafora, paradoks, atau hiperbola), dan salah satu penanda fonologi (rima, asonansi, konsonansi, atau aliterasi).

\section{Jenis Peribahasa}

Ada dua jenis peribahasa menurut Bhuvaneswar jika dilihat dari makna kata kunci yang digunakan (2000, 2-5).

1. Peribahasa literal memiliki makna yang sesuai dengan makna referensial unsur pembentuknya, contoh peribahasa Prancis: L'avarice perd tout en voulant tout gagner (harfiah: ketamakan kehilangan semua karena ingin memperoleh semua). Peribahasa itu terdapat di dalam kisah yang menceritakan seseorang yang tidak pernah merasa puas dengan apa yang dimilikinya, yang selalu ingin lebih. Kata kunci yang digunakan adalah kata l'avarice yang mengandungi makna 'quelqu'un qui acomportement de l'avare' (orang tamak) dan perd yang mengandungi makna 'ne plus avoir' (kehilangan) dalam menyampaikan pesan. Kata kunci yang digunakan memperlihatkan bahwa makna referensial peribahasa itu ditujukan langsung pada pesan yang disampaikan. Dengan demikian, makna peribahasa sama dengan makna referensial ujaran peribahasa itu.

2. Peribahasa kiasan menggunakan majas, seperti simile, hiperbola, paradoks, dan metafora, contoh peribahasa Indonesia tong kosong nyaring bunyinya. Peribahasa itu digunakan ketika seseorang banyak berbicara, tetapi tidak ada isinya. Kata kunci yang digunakan adalah frase tong kosong dan kata nyaring. Peribahasa itu menggunakan majas metafora, yaitu dengan mengumpamakan manusia dengan tong kosong. Dipilih frase tong kosong karena kondisi yang sama antara tong kosong dan manusia, yakni tong kosong berbunyi lebih nyaring dibandingkan tong yang berisi sesuatu. Kondisi itu disamakan dengan manusia yang tidak berilmu akan lebih banyak berbicara dibandingkan manusia yang berilmu, yang bicaranya ada isinya. Dengan demikian, makna peribahasa itu adalah makna referensial yang berasal dari makna majas yang digunakan.

\section{Penerjemahan Peribahasa}

Dalam menerjemahkan peribahasa Prancis ke bahasa Indonesia, penulis ini menggunakan teori Nida dan Taber $(1974,12)$ yang kemudian dikembangkan oleh Benny $(2006,11)$. Menurut Nida dan Taber, terdapat tiga tahapan penerjemahan, yakni analisis (memahami TSu), transfer (mengalihkan pesan atau menerjemahkan dalam pikiran), dan restrukturisasi (mengungkapkan pesan dalam bahasa sasaran). Untuk mendukung ketiga 
Benny $(2006,11)$ menambahkan empat tataran penerjemahan. Pada dasarnya, keempat tataran itu sama dengan tiga langkah penerjemahan Nida dan Taber. Keempat tataran itu merupakan penjabaran detil dari tiga langkah penerjemahan Nida dan Taber. Tataran pertama dan kedua menyangkut TSu, sementara itu, tataran ketiga dan keempat menyangkut TSa. Keempat tataran itu: (1) tataran teks, yaitu ketika penerjemah mencoba memahami teks yang harus diterjemahkan terutama pada tataran kata dan kalimat; (2) tataran referensial, yaitu penerjemah keluar dari teks untuk mengetahui apa yang dirujuk oleh suatu kata, istilah, atau ungkapan dalam teks bersangkutan; (3) tataran kohesi, yakni memeriksa kepaduan teks terjemahan; (4) tataran kewajaran, yakni memeriksa kejelasan dan keberterimaan bagi pembaca sasaran.

Berikut gabungan tahapan penerjemahan Nida dan Taber dan Benny (Ibid.), berdasarkan pemahaman penulis ini.

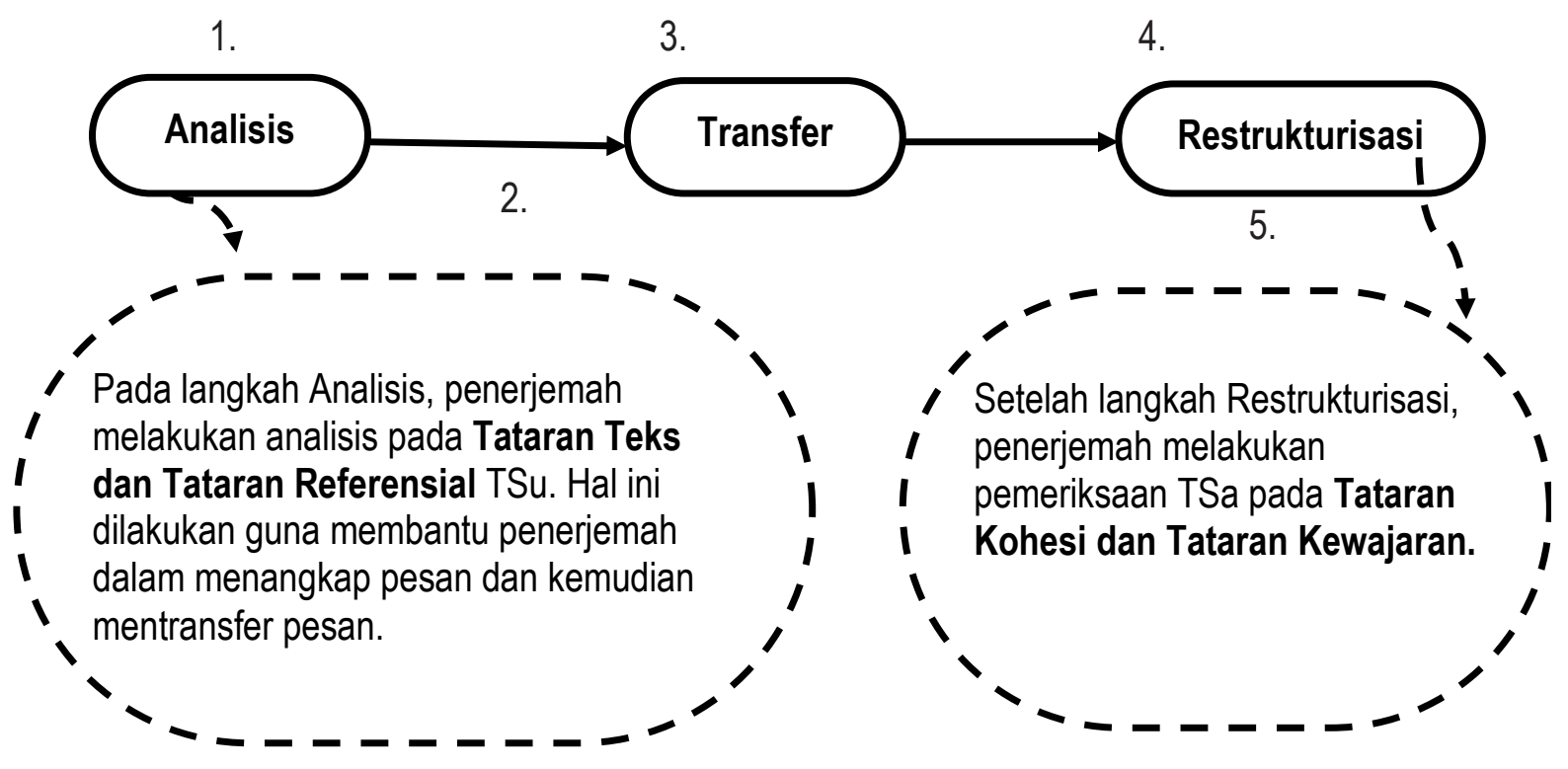

Gambar 1. Gabungan Langkah Penerjemahan Nida and Taber dan Benny

Ket:

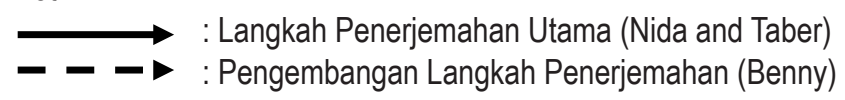

Dalam penelitiannya, penulis ini hanya akan menggunakan dua tataran Benny, yaitu tataran pertama dan kedua guna menemukan maksud peribahasa dan kata kunci yang digunakan.

Dalam penelitian ini data diambil dari enam belas fabel Jean de La Fontaine berikut terjemahannya dalam bahasa Indonesia. Penelitian ini berlangsung dalam tiga langkah. Pertama, menemukan arti peribahasa berdasarkan konteks cerita. Kedua, menemukan kata kunci peribahasa berdasarkan analisis tataran tekstual. Ketiga, menentukan jenis peribahasa dengan menggunakan teori Bhuvaneswar dan kemudian mengelompokkan data berdasarkan jenis peribahasa.

Hasil analisis menunjukkan bahwa enam belas peribahasa BSu terdiri atas lima belas peribahasa literal yang diterjemahkan dengan enam peribahasa kiasan BSa dan sembilan parafrase dan satu peribahasa kiasan yang diterjemahkan dengan peribahasa kiasan BSa. Masalah besar dalam penerjemahan peribahasa Prancis adalah ketiadaan padanan peribahasa BSa. Hal itu disebabkan oleh perbedaan jenis peribahasa antara peribahasa BSu dan BSa yaitu, peribahasa BSu berjenis peribahasa literal, sedangkan peribahasa BSa berjenis peribahasa kiasan.

Berikut tabel yang merangkum hasil analisis. 
Tabel 1. Terjemahan dan Jenis Peribahasa

\begin{tabular}{|c|c|c|c|c|c|}
\hline \multirow[t]{2}{*}{ No } & \multicolumn{2}{|c|}{$\begin{array}{l}\text { (A) } \\
\text { TSu }\end{array}$} & \multicolumn{2}{|c|}{$\begin{array}{l}\text { (B) } \\
\text { TSa }\end{array}$} & \multirow{2}{*}{$\begin{array}{c}\text { Jenis Peribahasa } \\
\text { Kiasan }\end{array}$} \\
\hline & Peribahasa BSu & Peribahasa BSa & Parafrase & Literal & \\
\hline 1. & $\begin{array}{l}\text { Tout flatteur } \\
\text { Vit aux dépens } \\
\text { de celui qui } \\
\text { l'écoute }\end{array}$ & $\begin{array}{l}\text { Mati ikan karena } \\
\text { umpan, mati } \\
\text { sahaya karena } \\
\text { budi }\end{array}$ & & $1 \mathrm{~A}$ & 1B \\
\hline 2. & $\begin{array}{l}\text { Les petits ont } \\
\text { pâti des sottises } \\
\text { des grands. }\end{array}$ & $\begin{array}{l}\text { Gajah berjuang } \\
\text { sama gajah, } \\
\text { pelanduk mati di } \\
\text { tengah-tengah. }\end{array}$ & & & $\begin{array}{l}2 A \\
2 B\end{array}$ \\
\hline 3. & $\begin{array}{l}\text { On a souvent } \\
\text { besoin d'un plus } \\
\text { petit que soi. }\end{array}$ & $\begin{array}{l}\text { Harimau putung } \\
\text { kena penjara, } \\
\text { pelanduk kecil } \\
\text { menolakkan }\end{array}$ & & $3 \mathrm{~A}$ & $3 B$ \\
\hline 4. & $\begin{array}{l}\text { Car c'est double } \\
\text { plaisir de tromper } \\
\text { le trompeur. }\end{array}$ & $\begin{array}{l}\text { Belut kena } \\
\text { ranjau. }\end{array}$ & & $4 \mathrm{~A}$ & $4 \mathrm{~B}$ \\
\hline 5. & $\begin{array}{l}\text { En toute chose } \\
\text { il faut considérer } \\
\text { la fin. }\end{array}$ & $\begin{array}{l}\text { Sedap jangan } \\
\text { ditelan, } \\
\text { pahit jangan } \\
\text { dimuntahkan } \\
\end{array}$ & & $5 A$ & $5 B$ \\
\hline 6. & $\begin{array}{l}\text { L'avarice perd } \\
\text { tout en voulant } \\
\text { tout gagner. }\end{array}$ & $\begin{array}{l}\text { Harapkan burung } \\
\text { terbang tinggi, } \\
\text { punai di tangan } \\
\text { dilepaskan. }\end{array}$ & & $6 \mathrm{~A}$ & $6 \mathrm{~B}$ \\
\hline 7. & $\begin{array}{l}\text { On tient toujours } \\
\text { du lieu dont on } \\
\text { vient. }\end{array}$ & $\begin{array}{l}\text { Asalnya kuda } \\
\text { itu kuda juga } \\
\text { dan keledai itu } \\
\text { keledai juga. }\end{array}$ & & $7 \mathrm{~A}$ & $7 \mathrm{~B}$ \\
\hline 8. & $\begin{array}{l}\text { Patience et } \\
\text { longueur de } \\
\text { temps } \\
\text { Font plus que } \\
\text { force ni que } \\
\text { rage. } \\
\end{array}$ & & $\begin{array}{l}\text { Kesabaran } \\
\text { dan waktu } \\
\text { yang panjang } \\
\text { lebih baik dari } \\
\text { kekuatan dan } \\
\text { kemarahan. } \\
\end{array}$ & $8 \mathrm{~A}$ & \\
\hline 9. & $\begin{array}{l}\text { Un tien vaut, ce } \\
\text { dit-on, mieux que } \\
\text { deux tu l'auras: } \\
\text { L'un est sûr, } \\
\text { l'autre ne l'est } \\
\text { pas. }\end{array}$ & & $\begin{array}{l}\text { Lebih baik kita } \\
\text { memiliki satu tapi } \\
\text { pasti, dari pada } \\
\text { dua tetapi tidak } \\
\text { pasti. }\end{array}$ & $9 \mathrm{~A}$ & \\
\hline
\end{tabular}




\begin{tabular}{|c|c|c|c|c|c|}
\hline \multirow[t]{2}{*}{ No } & \multicolumn{2}{|c|}{$\begin{array}{l}\text { (A) } \\
\text { TSu }\end{array}$} & \multicolumn{2}{|c|}{$\begin{array}{l}\text { (B) } \\
\text { TSa }\end{array}$} & \multirow{2}{*}{$\begin{array}{c}\text { Jenis Peribahasa } \\
\text { Kiasan }\end{array}$} \\
\hline & Peribahasa BSu & Peribahasa BSa & Parafrase & Literal & \\
\hline 10. & $\begin{array}{l}\text { Chacun à } \\
\text { son métier } \\
\text { doit toujours } \\
\text { s'attacher. }\end{array}$ & & $\begin{array}{l}\text { Setiap orang } \\
\text { memiliki } \\
\text { kemampuan } \\
\text { dalam } \\
\text { mengerjakan } \\
\text { sesuatu; } \\
\text { tetaplah pada } \\
\text { kemampuan itu. }\end{array}$ & $10 \mathrm{~A}$ & \\
\hline 11. & $\begin{array}{l}\text { le travail est un } \\
\text { trésor. }\end{array}$ & & $\begin{array}{l}\text { bekerja adalah } \\
\text { harta karun yang } \\
\text { sebenarnya. }\end{array}$ & $11 \mathrm{~A}$ & \\
\hline 12. & $\begin{array}{l}\text { Garde-toi, tant } \\
\text { que tu vivras, } \\
\text { De juger des } \\
\text { gens sur la mine. }\end{array}$ & & $\begin{array}{l}\text { Ingatlah selama } \\
\text { hidupmu, } \\
\text { Jangan menilai } \\
\text { seseorang dari } \\
\text { tampilan. }\end{array}$ & $12 \mathrm{~A}$ & \\
\hline 13. & $\begin{array}{l}\text { Rien ne sert } \\
\text { de courir, il faut } \\
\text { partir à point. }\end{array}$ & & $\begin{array}{l}\text { Tak ada gunanya } \\
\text { bergegas, lebih } \\
\text { baik berangkat } \\
\text { tepat waktu. }\end{array}$ & $13 \mathrm{~A}$ & \\
\hline 14. & $\begin{array}{l}\text { Il est bon de } \\
\text { parler, et meilleur } \\
\text { de se taire, }\end{array}$ & & $\begin{array}{l}\text { Berbicara itu } \\
\text { baik, tetapi diam } \\
\text { akan lebih baik, }\end{array}$ & $14 \mathrm{~A}$ & \\
\hline 15. & $\begin{array}{l}\text { Rien n'est si } \\
\text { dangereux qu'un } \\
\text { ignorant ami, } \\
\text { mieux vaudrait } \\
\text { un sage ennemi. }\end{array}$ & & $\begin{array}{l}\text { Seorang teman } \\
\text { yang bodoh, } \\
\text { lebih berbahaya } \\
\text { daripada musuh } \\
\text { yang bijak. }\end{array}$ & $15 \mathrm{~A}$ & \\
\hline 16. & $\begin{array}{l}\text { Quand le mal est } \\
\text { certain, } \\
\text { La plainte ni la } \\
\text { peur ne changent } \\
\text { le destin. }\end{array}$ & & $\begin{array}{l}\text { Ketika } \\
\text { kemalangan itu } \\
\text { pasti terjadi, baik } \\
\text { rintihan maupun } \\
\text { rasa takut tidak } \\
\text { dapat mengubah } \\
\text { takdir. }\end{array}$ & $16 \mathrm{~A}$ & \\
\hline
\end{tabular}

Tabel tersebut didapat dari analisis enam belas peribahasa Prancis dan terjemahannya dalam bahasa Indonesia. Berikut dua contoh analisis. Kedua contoh merupakan analisis yang dilakukan pada peribahasa BSu yang memiliki padanan parafrase. Analisis tidak hanya menjelaskan jenis peribahasa, tetapi juga menunjukkan kesulitan yang dihadapi ketika menerjemahkan. 


\begin{tabular}{|l|l|}
\hline \multicolumn{1}{|c|}{ BSu } & \multicolumn{1}{|c|}{ BSa } \\
\hline $\begin{array}{l}\text { Patience et longueur de temps } \\
\text { Font plus que force ni que rage. }\end{array}$ & $\begin{array}{l}\text { Kesabaran dan waktu yang panjang } \\
\text { lebih baik daripada kekuatan dan } \\
\text { kemarahan. (Prf.) }\end{array}$ \\
$\begin{array}{l}\text { (Kesabaran dan panjangnya waktu } \\
\text { melakukan lebih daripada kekuatan dan } \\
\text { kemarahan). }\end{array}$ & \\
\hline
\end{tabular}

Peribahasa itu ditemukan di dalam fabel yang berkisah tentang seekor singa yang ditolong oleh seekor tikus untuk melepaskan diri dari jerat. Menurut isi cerita, maksud dari peribahasa itu adalah kesabaran memang membutuhkan waktu yang lama, tetapi itu lebih baik daripada kekuatan dan kemarahan.

Pada tataran tekstual, kata kunci peribahasa tersebut adalah la patience yang mengandungi makna 'qualité qui fait qu'on persévère dans une activité, un travail de longue haleine, sans décourager' (kesabaran) dan la force yang mengandungi makna 'puissance d'action physique' (kekuatan fisik) dan la rage yang mengandungi makna 'envie violente, besoin passion' (kemarahan). Maksud peribahasa itu adalah kesabaran lebih baik dari kekuatan dan kemarahan. Kata kunci yang digunakan memperlihatkan bahwa makna referensial peribahasa itu ditujukan langsung pada pesan yang disampaikan. Dengan demikian, peribahasa BSu merupakan peribahasa literal, yaitu makna peribahasa sama dengan makna referensial dari ujaran peribahasa itu.

Pada tataran referensial, peribahasa BSu menunjukkan bahwa orang Prancis lebih mengutamakan kesabaran daripada kekuatan dan kemarahan. Itu berarti bahwa dalam menyelesaikan masalah hidup, orang Prancis lebih mengutamakan kecerdasan (kepala dingin), seperti berdialog atau bernegoisasi daripada menggunakan otot seperti berkelahi.

Merujuk pada analisis kedua tataran di atas, jika peribahasa tersebut diterjemahkan, terdapat peribahasa Indonesia yang mengutamakan kesabaran, yaitu sedikit demi sedikit lama-lama menjadi bukit, tetapi kurang tepat sebagai padanan karena maknanya agak berbeda. Peribahasa Indonesia digunakan ketika seseorang bersabar dalam mengumpulkan sesuatu, sedangkan peribahasa Prancis digunakan untuk orang yang menghadapi masalah. Dengan demikian, peribahasa BSu yang tepat diterjemahkan dengan parafrase.

\begin{tabular}{|l|l|}
\hline \multicolumn{1}{|c|}{ BSu } & \multicolumn{1}{|c|}{ BSa } \\
\hline $\begin{array}{l}\text { Il est bon de parler, et meilleur de se } \\
\text { taire. }\end{array}$ & $\begin{array}{l}\text { Berbicara itu baik, tetapi diam lebih baik. } \\
\text { (Prf) }\end{array}$ \\
(Itu baik berbicara, dan lebih baik diam). & \\
\hline
\end{tabular}

Peribahasa itu ditemukan di dalam fabel yang berkisah tentang seorang pecinta kebun yang celaka karena kebodohan beruang yang menjadi temannya. Menurut konteks cerita, maksud peribahasa itu adalah ketika kita tidak mengetahui atau memahami sesuatu, diam akan lebih baik.

Pada tataran tekstual, kata kunci peribahasa tersebut adalah parler yang mengandungi makna 's'exprimer' (berbicara) dan se taire yang mengandungi makna 'rester sans parler' (diam). Maksud peribahasa itu yaitu berbicara tentang apa yang disampaikan memang baik, tetapi diam akan lebih baik karena dengan diam kita dapat terhindar dari kemalangan. Dari kata kunci yang digunakan terlihat bahwa makna referensial 
peribahasa itu ditujukan langsung pada pesan yang disampaikan. Dengan demikian, peribahasa BSu adalah peribahasa literal karena makna peribahasa sama dengan makna referensial dari ujaran peribahasa itu.

Kedua, pada tataran referensial, konteks cerita menunjukkan bahwa orang Prancis akan diam saja ketika tidak atau kurang memahami apa yang akan disampaikan.

Merujuk pada analisis kedua tataran di atas, maksud peribahasa BSu sebetulnya mirip dengan peribahasa diam adalah emas, tetapi peribahasa BSa kurang tepat sebagai padanan karena alasan ini. Menurut sudut pandang orang Indonesia, diam adalah kegiatan yang mulia. Peribahasa BSa digunakan ketika seseorang memilih diam agar dirinya ataupun orang lain terhindar dari hal yang dapat menyakiti, sedangkan peribahasa BSu digunakan ketika seseorang tidak atau kurang memahami apa yang akan disampaikan. Dengan demikian, peribahasa BSu lebih tepat dipadanan dengan parafrase.

Maksud peribahasa BSa adalah diam adalah tindakan terpuji dan bijaksana daripada berbicara yang tidak memberikan manfaat apa-apa. Peribahasa itu menggunakan majas metafora, yaitu dengan memetaforakan makna 'diam' dengan makna 'emas'. Dipilih kata diam karena kondisi yang sama antara seseorang yang diam dan emas, yakni diam sebagai sesuatu yang berharga dan mulia. Kondisi itu disamakan dengan emas sebagai logam mulia yang berharga. Dengan demikian, peribahasa itu merupakan peribahasa kiasan karena makna peribahasa adalah makna referensial yang berasal dari makna majas yang digunakan.

Dari berbagai temuan penelitian ini, dapat disimpulkan beberapa hal. Menemukan padanan berupa peribahasa BSa dalam penerjemahan peribahasa Prancis ke dalam bahasa Indonesia bukan perkara mudah karena peribahasa merupakan kalimat beku yang memiliki ciri dan karakteristik unik. Salah satu ciri peribahasa adalah kata kunci yang digunakan untuk menyampaikan pesan. Kata kunci itu membantu penerjemah untuk mengetahui maksud dan jenis peribahasa. Dalam penelitian ini ditemukan lebih banyak peribahasa literal dalam bahasa Prancis, sedangkan sebagian besar peribahasa Indonesia adalah peribahasa kiasan. Perbedaan jenis peribahasa itu membuat penerjemah sulit menemukan padanan berupa peribahasa Indonesia.

Perbedaan jenis peribahasa tersebut tidak dapat dilepaskan dari perbedaan budaya Prancis dan Indonesia. Perbedaan budaya mengakibatkan perbedaan sudut pandang. Kebudayaan Prancis dipengaruhi oleh filsafat Barat, seperti humanisme dan positivisme, sedangkan kebudayaan Indonesia dipengaruhi oleh filsafat Timur. Adanya pengaruh budaya dalam penerjemahan itu sejalan dengan apa yang dinyatakan oleh Newmark (1988) dan Benny $(2006,79)$ bahwa penerjemahan yang melibatkan dua teks berarti juga melibatkan dua bahasa dan kebudayaan. TSu dan TSa sama-sama dipengaruhi oleh sejumlah faktor kebahasaan dan budya.

\section{DAFTAR REFERENSI}

Benny Hoedoro Hoed. 2006. Penerjemahan dan kebudayaan. Jakarta: PT. Dunia Pustaka Jaya.

Bhuvaneswar, Chilukuri. 2000. Derivation of Meaning in Proverbs: A Ka:rmik Linguistic Analysis. Working Paper 5 in Semantics 12th, July 2000, 2-4.

Honeck, Richard P. 1997. A Proverb in Mind: The Cognitive Science of Proverbial Wit and Wisdom. Mahwah,

$\mathrm{NJ}$ : Lawrence Erlbrum Associates.

Krishenblatt-Gimblett, Barbara. 1981. Toward a theory of proverb meaning. Dalam Wolgang Mieder dan Alan

Dundes, eds. The wisdom of many: Essays on the proverb, 122-139. New York: Garland.

Mieder, Wolfgang. 2004. Proverbs: A handbook. New York: Greenwood.

Mieder, W., dan Dundes, A., eds. 1995. The wisdom of many: Essays on the proverb. New York: Garland.

Nida, E dan Taber, C. 1974. The theory and practice of translation. Leiden: Brill. 
Norrick N. R. 1985. How proverbs mean: Semantic studies in English proverbs. New York: Mouton. Rey, Isabel González. 2002. La phraséologie du Français. Toulouse: Presses Universitaire du Mirail. 